\title{
ADAPTÍV WAVELET-ALAPÚ ZAJCSÖKKENTŐ ELJÁRÁS MOBILROBOT TÁVÉRZÉKELÉSI ADATFELDOLGOZÓ RENDSZERÉBEN
}

\section{ADAPTIVE WAVELET-BASED NOISE-REMOVAL METHOD FOR MOBILE ROBOT REMOTE SENSING DATA PROCESSING SYSTEM}

\author{
Dineva Adrienn ${ }^{1}$, Nagy István ${ }^{2}$ \\ ${ }^{I}$ Óbudai Egyetem, Alkalmazott Informatikai és Alkalmazott Matematikai Doktori \\ Iskola, 1034 Magyarország, Budapest, Bécsi út 96/b, dineva.adrienn@bgk.uni- \\ obuda.hu \\ ${ }^{1}$ Universitá degli Studi di Milano, Department of Information Technologies, \\ Doctoral School of Computer Science, I-26013, Olaszország, Crema (CR) Via \\ Bramante 65, adrienn.dineva@unimi.it \\ ${ }^{2}$ Óbudai Egyetem, Bánki Donát Gépész- és Biztonságtechnikai Mérnöki Kar, \\ Mechatronikai és Autótechnikai Intézet, 1081 Magyarország, Budapest, Népszínház \\ utca8.,nagy.istvan@bgk.uni-obuda.hu
}

\begin{abstract}
Filtering of remotely-sensed data of mobile robot is challenging due to the complex distribution of the environment and the various types of contaminating noises that may occur. Also the collected data contain much information that requires the appropriate pre-processing in order to generate the desired environment map of reconnaissance. In this paper a new approach has been proposed for denoising and processing remotely-sensed data. The proposed method utilizes the advantages of multiresolution analysis and robust fitting. It has been shown that it excellently removes both additive noise and unnecessary artifacts with retaining the important parts of the environment model. The method requires only low resolution levels and is able to avoid data loss.
\end{abstract}

Keywords: discrete wavelets transform, adaptive filter, outlier detection, remote sensing, mobile robot.

\section{Összefoglalás}

A mobilrobotok távérzékeléséből nyert adatainak zajszürése a kívánt pontosságú digitális környezetmodell elóállításához napjainkban is kihívást jelent. A távérzékelés során elöállított pontfelhő számos forrásból eredő torzításokat tartalmazhat. Jelen munkában a mobilrobotok távérzékelési rendszerében az adatok előfeldogozására alkalmas wavelet-alapú eljárást mutatunk be. A wavelet transzformáció segítségével alacsony felbontási szinten is jól elkülöníthető a zaj a jel fontos részleteit tartalmazó részeitől. Ezekre alkalmazva a robusztus illesztést az extrém értékek, torzítások is eltávolíthatóak, szemben a klasszikus wavelet alapú szürő eljárásokkal.

Kulcsszavak: wavelet transzformáció, adaptív szürö, outlier szürés, távérzékelés, mobil-robot. 


\section{Bevezetés}

A mobilrobot egyik jelentős csoportját alkotják az „,̈nállóan navigáló járművek” (AGVs - Automatic Guided Vehicles). Az ilyen járművek pontos navigációjának legfontosabb sarokköve a környezet legpontosabb ismerete. A környezetről való információ gyüjtése különféle érzékelöcsoportok segítségével történhet. Ezek közül a leggyakrabban használatosak az ultrahangos érzékelök, különböző látórendszerek (kamerás rendszerek, hibrid: kamera-lézer kombinációk), radarok. Ezek az érzékelők a mélységméréshez általában két alapvető módszert használnak: a fáziseltolás mérését a kibocsátott és a visszaverődött hullám között (phase-shift method); repülési idő mérését (TOF method). Mindkét esetben a mért eredmények egy adatbázisba kerülnek, ami valójában a környezet ún. „szenzortérképe”, vagyis a nyers mérési adatok halmaza. A szenzorcsoportokat gyakran kombinálják, azért, hogy a térbeli közeg szennyezettségétöl függetlenül, a nyers adatok a lehető legpontosabbak legyenek. Gyakran alkalmaznak kamera-lézer kombinációkat, ahol a sztereó-kamera rendszer, tiszta látási körülmények között, képes majdnem ideális környezeti modellezésre, viszont füsttel/köddel/egyéb vegyi anyagokkal szennyezett légtérben a kamerás mélységmérést ki kell egészíteni lézeres sor-szkennerrel. Igaz, a lézersugár is érzékeli a szennyeződéseket, viszont ezeknek szürésére hatékony digitális szürők állíthatók fel. Végül a lézeres mélységmérés és a részleges kamerakép fúziójából kerül összeállításra a végleges környezeti modell. Ismeretlen környezetben navigáló mobilrobotok elöször feltérképezik környezetüket, majd elhelyezik magukat ebben a környezetben (lokalizálás), és ezek után megtervezik az akadálymentes útvonalat ebben a környezetben. Ez az eljárás „egyidejü lokalizáció és térképkészités" (SLAM) néven ismeretes, ahol az adatfeldolgozás gyorsasága kritikus kérdés, ezért a lehetó leghatékonyabb szürési eljárást kell alkalmaznunk. Továbbá, a lokalizációs eljárás megkezdéséhez ismernünk kell egy kiindulási pontot, ahova a koordinátarendszerünk origóját elhelyezzük. Amennyiben ez adott a környezettel (pl. 3 vagy több természetes markertől megállapítjuk pozíciónkat), akkor oda felvesszük a kiinduló koordinátát, viszont amikor nem lehetséges, akkor egy relatív kiindulási pontot alkalmazunk, ami lehet, pl. az aktuális pozíciónk. Mindkét esetben, a további sikeres navigáció érdekében, ismernünk kell, a kiindulási pozíciótól és orientációtól megtett utunkat, szögelfordulásainkat. Ezeket a mobilrobot a belső szenzorai (odométer, giroszkóp) segítségével méri. A pontos lokalizálás nagyon fontos, úgy a navigáció, mint a térképkészítés folyamatában. Végül a térképkészítés egy komplex matematikai müvelet eredménye, amely a megszürt mélységmérési adatokkal, a lokalizációs és orientációs adatokkal számol. A távérzékelés során nyert háromdimenziós pontfelhő számos forrásból eredő torzításokat tartalmazhat. A kívánt környezeti modell elöállításához kulcsfontosságú ennek megfelelő előfeldolgozása. Ismert, hogy a wavelet alapú zajszürés (wavelet shrinkage) igen hatékony és széles körben elterjedt eljárás. Azonban az alkalmas wavelet küszöbfüggvény kiválasztása napjainkban is kihívást jelent a felhasználók számára, mivel az alkalmazott módszer jelentős hatással van az eredményre. Továbbá az eljárásban alkalmazott wavelet függvény specifikus megválasztása, a felbontási szintek száma, stb., nagyszámú szürö eljárást tesz lehetővé. Mindemellett a különböző típusú zajokat, ill. csatorna tulajdonságokat is figyelembe kell venni. 
Az adott feladat követelményeitől függően szükséges lehet bizonyos térelemek eltávolítása is, melyek a nyers adathalmazban zajként, kiugró értékü, ún. outlier elemekként jelentkeznek. Ezért ebben a munkában egy wavelet-alapú szürö stratégiát mutatunk be, mely egyidejüleg eltávolítja a különböző típusú zavarokat, csökkenti a mérési hibákból esetlegesen eredő torzításokat, illetve a bevezetett adaptív szabály segítségével lehetővé teszi a kívánalomnak megfelelő részletességü környezeti model előállítását.

\section{Wavelet-alapú zajcsökkentő eljárások}

A wavelet analízis egyik legelterjedtebb felhasználási területe a különböző zajcsökkentő eljárások, ahol a jelet együtthatók halmazára bontják le, melyek a jel szórását írják le különböző skálákon. A kívánt felbontás az, ahol minél kevesebb elem reprezentálja a jelet, míg a többi a zaj középértékével van kapcsolatban. Ahhoz, hogy az ilyen dekompozíciót megvalósíthassuk, megfelelő wavelet függvényt kell alkalmazni. A wavelet-alapú szürés (wavelet shrinkage), ill. a wavelet küszöbölés (wavelet thresholding) elve azon alapul, hogy a ,wavelet atomokra" [1] alkalmazunk egy ún. küszöb-függvényt majd elvégezzük az inverz diszkrét wavelet transzformációt [2][3][4]. A wavelet küszöbölés egy standard eljárás a jelek zajcsökkentésére. Eredetileg a redukált, alacsony értékủ együtthatókat nullával helyettesítjük, a nagyokat változatlanul hagyjuk (hard thresholding)

$$
\eta\left(w_{i j}\right)=\left\{\begin{array}{cc}
w_{i j} & \text { ha: } w_{i j}>T \\
0 & \text { egyébként }
\end{array}\right\}
$$

vagy pedig a küszöbértékére csökkentjük , azaz lágy küszöbölést alkalmazunk (soft thresholding).

$\eta\left(\mathrm{w}_{\mathrm{ij}}\right)=\operatorname{sign}\left(\mathrm{w}_{\mathrm{ij}}\right), \max \left(\left(\left|\mathrm{w}_{\mathrm{ij}}\right|-T\right), 0\right)$ ahol $\eta\left(\mathrm{w}_{\mathrm{ij}}\right)$ a lágy küszöbfüggvény, melyet a $w_{\mathrm{ij}}$ wavelet együtthatókra alkalmazunk, $\quad \boldsymbol{T}$ a küszöbérték [5]. A küszöbérték meghatározására számos megközelítés született, többek közt az együtthatók fuzzy klaszterezés segítségével történő osztályozása. A [6] közleményben digitális képek zajcsökkentésére tett javaslat szerint érdemes először fuzzy k-közép klaszterezési eljárással minden al-sávra meghatározni a küszöböt a lágy-küszöbölési eljáráshoz, majd ezután a küszöb értékére csökkenteni a kiugró értékű elemeket. A felbontási szintek számának nagymértékü növelése nem javítja az eredményt, azonban a rekonstrukció szempontjából a jel tulajdonságait hordozó fontos elemeket elvesztését eredményezi. Donoho és Johnstone [7] munkájukban mutatták be a SureShrink eljárást, mely minden diadikus wavelet felbontási szinten a Sure (Stein's Unbiased Estimate of Risk, lásd [8]) becslési eljárást alkalmazza a küszöb meghatározására. Jelenleg a gyakorlatban legelterjedtebb eljárások például a SureShrink, illetve a minimax küszöbölés, heurisztikus Sure és az univerzális korlát (universal bound) [7]. A [4]-ben ismertetettek alapján az univerzális korlát például a következö:

$$
\eta_{1}=\sigma_{\mathrm{MAD}} \sqrt{2 \log \mathrm{s}_{\mathrm{j}}}
$$

ahol $\quad \sigma_{\mathrm{MAD}}=\frac{\operatorname{median}\left(\mid \underline{\mathrm{w}}_{\mathrm{j}}\right)}{0.6745} \quad$ a $\quad$ közepes abszolút eltérés. Míg a HeurSure módszer pedig a heurisztikus kombinációja a SureShrink és az univerzális korlát (universal bound) eljárásoknak [7].

\section{Mobilrobot távérzékelési adatainak adaptív szürése}

Az outlier-ek (véletlenszerü, szélső elemek, ill. a normál zajszinten felüli értékek) eltávolítására a nem parametrikus regressziós módszerek (ún. 'scatterplot 
smooths') körébe tartozó robusztus 'loess' (robust locally weighted polynomial regression) az egyik leghatékonyabb eljárás, mely tulajdonképpen a „futó egyenes" (running line) illetve a kernel regresszió keverékének tekinthető. A hatékonyságának egyik kulcsa, hogy az ún. „,csúszó ablakban” az aktuális elemtől való távolság függvényében csökkenő súlyszámot kapnak az elemek, majd a hibatagok szerinti iteratív újrasúlyozással (pl. duplanégyzet függvénnyel) nyerjük az ún. robusztus súlyokat, amellyel befolyásolhatjuk a függvény illesztését.

\subsection{Az eljárás ismertetése}

$\mathrm{Az}$ általunk bevezetett eljárás összekovácsolja a robusztus illesztés és a wavelet felbontás előnyeit. Ezek kombinációjával igen gyors és pontos eljárást dolgoztunk ki, mely alkalmas földi mobilrobotok real-time távérzékelési adatfeldolgozó rendszerének előfeldolgozási feladatait ellátni. A "klasszikus" küszöbölö függvények helyett az atomokra alkalmazva a módosított adaptív robusztus illesztést, könnyen eltávolíthatóak a nem kívánt részletek. Azonban a megfelelő illesztéshez, mind az elemek távolságának a csúszó-ablakban, mind a polinom paramétereinek, stb., a megfelelő értékeket kell adnunk. Továbbá, a paraméterek befolyásolják, milyen részleteket tudunk megtartani a környezetmodellből. Ehhez olyan adaptív szabályt dolgoztunk ki, mely a különböző térbeli objektumok komplexitásának függvényében határozza meg a simító-, ill. "robusztus" paramétereket így biztosítva, hogy az eredményül nyert modell a kívánt információt megtartsa.

\section{4. Összefoglalás}

Jelen közleményben egy új, adaptív wavelet-alapú zajcsökkentő eljárás került bemutatásra a mobilrobotok távérzékelési adatfeldolgozó rendszerében. A fentebb ismertetett módszer, a valósidejü környezetmodellezési feladatok esetén, alkalmas egyidejüleg eltávolítani a különböző típusú zavarokat, csökkenti a mérési hibákból esetlegesen eredő torzításokat, illetve a bevezetett adaptív szabály segítségével lehetővé teszi az elvártaknak megfelelő részletességü környezeti modell előállítását.

\section{Köszönetnyilvánítás}

A kutatásokat az OTKA (105846) támogatta.

\section{Szakirodalmi hivatkozások}

[1] S. Mallat: Multiresolution Approximations and Wavelet Orthonormal Bases of L2, Trans. Am. Math. Soc., 1989, pp. 69-78

[2] I. Daubechies: Orthonormal Bases of Compactly Supported Wavelets, Comm. Pure \& Appl. Math. 41, 1988, pp. 909-996.

[3] I. Daubechies: The Wavelet Transform, Time Frequency Localization and Signal Analysis, IEEE Trans. Inform. Theory 36, 1990, pp. 961-1005

[4] D.L. Donoho: Progress in Wavelet Analysis and WVD: a ten minute tour, Wavelet Analysis and Applications, Y. Meyer, S. Roques(Eds.), Frontières, 1993, pp. 109-128

[5] D. L. Donoho: Ideal Spatial Adaptation via Wavelet Shrinkage, Biometrika 81, 1994, pp. 425-445

[6] M. Mastriani, A. Giraldez: Fuzzy Thresholding in Wavelet Domain for Speckle Reduction in Synthetic Aperture Radar Images, ICGST Int. J. of Artificial Intelligence and Machine Learning, Vol 5, 2005, [Online]. Available: ttp://www.icgst.com/aiml/v3/index.html

[7] D.L. Donoho, I.M. Johnstone: Adapting to Unknown Smoothness via Wavelet Shrinkage, Journal of the American Statistical Association 90, 1995, pp. 12001224

[8] C.M. Stein: Estimation of the Mean of a Multivariate Normal Distribution, The Annals of Statistics 9 (6), 1981, pp. 11351151 